\title{
Freeze-Drying Versus Spray-Drying of CWBI-B1465 Leuconostoc mesenteroides subsp. mesenteroides Isolated in kivuguto Milk
}

\author{
Eugene Karenzi*, Jacqueline Destain, Philipe Thonart \\ Gembloux Agro-Bio Tech, University of Liege, Gembloux, Belgium
}

Email address:

eugene.karenzi@doct.ulg.ac.be (E. Karenzi)

To cite this article:

Eugene Karenzi, Jacqueline Destain, Philipe Thonart. Freeze-Drying Versus Spray-Drying of CWBI-B1465 Leuconostoc mesenteroides subsp. mesenteroides Isolated in kivuguto Milk. Advances in Bioscience and Bioengineering. Vol. 3, No. 3, 2015, pp. $20-29$.

doi: $10.11648 /$ j.abb.20150303.11

\begin{abstract}
The strain CWBI-B1465 Leuconostoc mesenteroides has been previously selected from traditional kivuguto, a fermented milk from Rwanda. The strain is preserved in the CWBI Collection and the sequence is deposited in GenBank under Accession number JF313445. The paper reports the production and the preservation of that strain for dairy starter culture use. The production was carried out in a $20 \mathrm{~L}$ fermentor with $16 \mathrm{~L}$ working volume in batch process. Half of this was centrifuged. The cells were harvested, cryoprotected and freeze-dried. The freeze-dried powders were then vacuum-sealed and stored for 90 days. The other half was also centrifuged. The cells were harvested, mixed with protectants and spray-dried. The spray-dried powders were then vacuum-sealed and stored for 90 days. After the two drying processes, viability in storage at 4 and $20^{\circ} \mathrm{C}$ was examined on six levels: membrane fatty acids, flow cytometry, soluble proteins, carbonyl proteins and enumeration on agar MRS. The production was also made in a $20 \mathrm{~L}$ fermentor with a $16 \mathrm{~L}$ working volume in a fed-batch process, only for optimal production assessment. The obtained results showed that CWBI-B1465 grows at $0.55-0.60 \mathrm{~h}^{-1}$ of the specific growth rate; the generation time was 1.12 and $1.25 \mathrm{~h}$ in batch and fed-batch, respectively. Its preservability exhibited low loss when it is stored at $4^{\circ} \mathrm{C}$, and more if it is stored at $20^{\circ} \mathrm{C}$. The most suitable drying process is freeze-drying, but spray-drying is also very interesting and is recommended based on the cost of the process.
\end{abstract}

Keywords: Freeze-Drying, Spray-Drying, Leuconostoc

\section{Introduction}

Spray-drying can be used to produce large amounts of dairy ingredients relatively inexpensively; the spray-dried powders can be transported at a low cost and can be stored in a stable form for prolonged periods [1]. Suitable strain selection necessitates consideration of three essential premises: encompassing general aspects (origin, identity, safety), technological aspects (growth properties during processing, survival during processing and storage) and stability of functional properties [2-4]. Spray-drying can produce stable powders of certain bacteria and yeast species; however, with the high temperatures involved in this process, the species require a certain level of thermotolerance [5]. The overall viability and subsequent oxidative damage affect primarily lipid membranes, proteins and DNA along the whole process. Polyunsaturated fatty acids and amino acid oxidation (primarily Pro, Arg, Lys and Thr), as well as protein fragmentation and protein aggregation, are the major damages for dried bacteria in storage. They are degraded into a variety of products [6-11] under many biochemical reactions. Among of them, the carbonylation is a chemical reaction that produces organic carbonyl compounds containing the $\mathrm{C}=\mathrm{O}$ functional group, including aldehydes and ketones [12]. Protein carbonylation was therefore examined as a potential cause for dried bacteria's loss of viability. The reagent 2,4-dinitrophenylhydrazine (DNPH) reacts with the aldehyde or ketone carbonyl group and forms hydrazone derivatives (DNP), thus enabling spectrophotometric determination [13-14].

In this study, the strain CWBI-B1465 was investigated based on its ability to withstand the stresses associated with high temperature and acidity because it resists well to $55^{\circ} \mathrm{C}$ and a $\mathrm{pH}$ of 2.5 [15]. In this regard, our hypothesis was that it 
could also withstand stresses of spray-drying. Therefore, production in the bioreactor and drying by freeze-drying in parallel to spray-drying was a suitable process allowing for understanding the level of resistance of this strain. Data of this comparative study will allow us to know the most suitable process to be used for its preservation as a dairy starter culture.

The aims of this study were therefore:

i. To examine the yields of growth during production;

ii. To evaluate viability during freeze/spray-drying and storage.

\section{Material and Methods}

\subsection{Bacterial Strains and Cultures}

From the CWBI Collection preserved at $-80^{\circ} \mathrm{C}$, the strain CWBI-B1465 Leuconostoc mesenteroides subsp. mesenteroides JF313445 was cultured on MRS agar and incubated for 36 hours at $30^{\circ} \mathrm{C}$. Thereafter, it was inoculated in $500 \mathrm{~mL}$ of MRS broth as a pre-culture of a 20 L bioreactor (Biolafitte, Poissy, France).

\subsection{Fermentation Processes}

\subsubsection{Batch Fermentation}

All batch fermentations were carried out in triplicate in a 20 L bioreactor (Biolafitte, Poissy, France) with a 16 L working volume. Then, $1 \mathrm{~L}$ of glucose solution at $20 \mathrm{~g}$. $\mathrm{L}^{-1}$ was added just before fermentation. The regulation of the culture parameters ( $\mathrm{pH}$, temperature, alkali, etc.) was ensured by a direct control system (ABB). The culture in the bioreactor was held at $27^{\circ} \mathrm{C}$ and at a $\mathrm{pH}$ of 6.5 , with a constant stirring speed of $100 \mathrm{rpm}$ with air flow. The foam level in the reactor was controlled by an antifoam probe placed at $10 \mathrm{~cm}$ from top of the vessel and by the addition of antifoam Tego KS911 (Goldschmidt, Germany). The inoculum for the bioreactor was prepared in MRS broth autoclaved in a $1 \mathrm{~L}$ flask filled halfway. It was prepared by inoculating some colonies of the bacterium grown on the MRS agar plate. The growth kinetic parameters were calculated following the Monod equation:

$$
\mu_{=} \mu_{\mathrm{m}} \frac{\mathrm{s}}{\mathrm{S}+\mathrm{Ks}}
$$

where $\mu$ is the specific growth rate: $\mu=r_{x} / X$, with $X$ the biomass concentration (cells dry matter). The cell yield $\left(\mathrm{Y}_{\mathrm{X} / \mathrm{S}}\right)$ (g cells dry matter/g glucose) was calculated from plots of $\mathrm{X}-\mathrm{X}_{0}$ vs. S-S0 [16]:

$$
\mathrm{Y}_{\mathrm{X} / \mathrm{S}}=\frac{\mathrm{X}-\mathrm{X} 0}{\mathrm{~S}-\mathrm{S} 0}
$$

where $\mathrm{X}$ and $\mathrm{Xo}$ are the biomass concentrations at $\mathrm{t}$ time and the initial time $\mathrm{t}_{0}$ respectively; $\mathrm{S}$ and $\mathrm{S} 0$ the residual glucose (g. $\left.\mathrm{L}^{-1}\right)$ at $\mathrm{t}$ time and $\mathrm{t}_{0}$ time.

\subsubsection{Fed-Batch Fermentation}

The fed-batch culture conditions are the same as the batch culture. The conditions of the culture differ only to the second glucose solution of $1 \mathrm{~L}$ added just before seven hours. Fed-batch fermentation was conducted to increase biomass production.

\subsection{Down-Stream Process}

\subsubsection{Concentration \& Protective Agent Addition}

At the end of fermentation, the cultures were harvested and centrifuged at $4{ }^{\circ} \mathrm{C}$ and $4700 \mathrm{rpm}$ for $40 \mathrm{~min}$ in a Sorvall ${ }^{\circledR}$ RC12BPTM centrifuge (Thermo Scientific Inc., Massachusetts, USA). Eight liters were concentrated by centrifugation for a further lyophilization and the other eight for atomization.

\subsubsection{Freeze-Drying}

The fresh paste was weighted and diluted with one quarter of the supernatant solution and was mixed for paste recovery from the centrifuge pots. Thereafter, the cream obtained was supplemented with $2 \%$ of glycerol and $5 \%$ of maltodextrin as cryoprotectants, well malaxed and stored at $-20^{\circ} \mathrm{C}$ before the freeze-drying process (Lyophilizator Liogamma, Koeltechniek Louw B.V.B.A, Rotselaar, Belgium). The freeze-drying operation lasted 20 hours and the pressure stayed at 0.6 mbar. Next, samples of the freeze-dried cells were vacuum-sealed in metallo-plastic bags. Then, the bags were stored at $4{ }^{\circ} \mathrm{C}$ and $20^{\circ} \mathrm{C}$ for oxidation analyses after lyophilization (1 day), and at 15, 30, 60 and 90 days. This method was complemented by enumeration on MRS agar.

\subsubsection{Spray-Drying}

The cream was obtained using procedures similar to the freeze-drying process. Once weighed, the supernatant at four-fold the weight of the cream was first mixed with the protective agents under agitation during one hour for feed solution preparation. As protective agents, half of the cream weight made by casein pepton and the other half by maltodextrin were prepared. The feed solution was atomized using a GEA Niro spray-dryer (Sœborg, Denmark) under the following conditions: outlet air temperature $50^{\circ} \mathrm{C}$, inlet air temperature $150^{\circ} \mathrm{C}$ and atomizing air pressure four bars. These conditions were obtained after many assays in search of the best yield. Powder was collected in a single cyclone separator in glass bottles and was vacuum packed (Audion Elektro, Weesp, Netherlands) in metallo-plastic bags and stored at 4 and $20^{\circ} \mathrm{C}$ up to 90 days. The outlet temperature was maintained at $50-55^{\circ} \mathrm{C}$ to obtain powders with the least moisture $(5 \%)$ and to control the flow rate.

Moisture content in freeze/spray-dried powders: The moisture content of dried powders was determined by oven drying at $105^{\circ} \mathrm{C}$ according to the International Dairy Federation Bulletin [17].

\subsection{Analytical Methods}

\subsubsection{Determination of the Viability}

After each drying process, the survival rate was calculated as follows: 


$$
\text { Survival rate }(\text { yield } \%)=100 \frac{C p}{D p} \cdot \frac{D i n}{C i n} \text {, }
$$

where:

- $\mathrm{Cp}$ is the concentration of powder (the outlet concentration in cfu. $\left.\mathrm{g}^{-1}\right)$;

- Dp is the outlet dry matter (of powder) (\%);

- Cin is the inlet concentration (of cream) (in cfu. $\mathrm{g}^{-1}$ );

- Din is the inlet dry matter (of cream) (\%).

The concentration before and after freeze/spray-drying was determined as colony forming units (cfu) per $\mathrm{g}$ or per $\mathrm{mL}$. Suitable decimal dilutions were prepared for enumeration and plated on MRS agar. After 90 days of storage, the survival rate was calculated according to the relation:

$$
\text { Survival rate }(\%)=\frac{\mathrm{N}}{\mathrm{No}},
$$

with $\mathrm{N}$ being the cell concentration (cfu. ${ }^{-1}$ ) of the freeze-dried samples at 90 days of storage and No being the cell concentration ( $\mathrm{cfu}^{-1} \mathrm{~g}^{-1}$ ) after freeze/spray-drying process.

\subsubsection{Analysis of Fatty Acids Extracted from Cell Membrane}

The lipids were extracted following a protocol Zelles [18] developed. The fatty acid fraction was extracted from $1 \mathrm{~g}$ of freeze-dried cells according to the adapted method [19]. After two hours of extraction on a fixed speed rotator SB2 of Stuart ${ }^{\circledR}$ (Chelmsford, Essex, UK ) from cell wall fractions of dried cells in $15 \mathrm{~mL}$ of an ethanol-ether $(3: 1 \mathrm{v} / \mathrm{v})$ mixture, the ethanol ether extracts were filtered on nylon membrane filters, Nylaflo ${ }^{\mathrm{TM}}$ (Pall life Sciences, Mexico, Mexico) of 0.2 $\mu \mathrm{m}$ pore size, with $47 \mathrm{~mm}$ of diameter and then evaporated on a Büchi Rotavapor ${ }^{\circledR} \mathrm{R}-200$ (Büchi Labortechnik AG, Flawil, Switzerland) coupled to a Büchi ${ }^{\circledR}$ Heating Bath B-490 (Büchi Labortechnik AG, Flawil, Switzerland) and concentrated under reduced pressure at $55-61^{\circ} \mathrm{C}$. Fatty acid esters extract was then prepared from the concentrate with 14 $\%(\mathrm{w} / \mathrm{w})$ solution of boron trifluoride $(0.5 \mathrm{~mL})$ and $0.2 \mathrm{~mL}$ of $\mathrm{n}$-hexane. The suspension was thereafter submitted to a trans-esterification process at $70^{\circ} \mathrm{C}$ in a water bath for 90 min; $0.5 \mathrm{~mL}$ of saturated $\mathrm{NaCl}, 0.2 \mathrm{~mL}$ of sulfuric acid $(10 \%)$ and $4 \mathrm{~mL}$ of $\mathrm{n}$-hexane were added. The fatty acids were extracted from the upper phase after five minutes. Gas chromatographic analysis of the fatty acid methyl esters (FAME) was carried out on a HP 6890 (Hewlett Packard) gas chromatograph equipped with a flame ionization detector at $250^{\circ} \mathrm{C}$. A capillary column $(30 \times 0.25 \mathrm{~mm}$, film thickness 0.25 $\mu \mathrm{m})$ was used. The conditions were as follows: the carrier gas was helium $(2.4 \mathrm{~mL} / \mathrm{min})$ and the injection volume was 1 $\mu \mathrm{L}$. Injection was done at $250^{\circ} \mathrm{C}$ in the splitless mode for 1 $\mathrm{min}$. The oven temperature was held at $50^{\circ} \mathrm{C}$ for $1 \mathrm{~min}$, increased by $30^{\circ} \mathrm{C} / \mathrm{min}$ to $150^{\circ} \mathrm{C}$ and then from $150^{\circ} \mathrm{C}$ to $240^{\circ} \mathrm{C}$ at $4{ }^{\circ} \mathrm{C} / \mathrm{min}$ with a final hold of $10 \mathrm{~min}$ at $240^{\circ} \mathrm{C}$. Fatty acids methyl esters were identified by comparing their retention times with standard mixtures FAME MIX $47885 \mathrm{U}$ (Supelco, Bellefonte, USA). The relative fatty acid content was estimated as a relative percentage of the total peak area using a DP 700 integrator (Spectra physics). Analyses were made in triplicate. All chemicals were analytical grade reagents.

\subsubsection{Flow Cytometry Analyses}

The experiments were carried out on a BD FACSCalibur system composed of a FACSCalibur two lasers flow cytometer and CellQuest software (BD Biosciences, San Jose, California, USA). For viability assessment of the freeze/spray-dried cells, the carboxyfluorescein diacetate (cFDA) and the dye exclusion DNA binding probes propidium iodide (PI) were used for live and dead discrimination. $1 \mathrm{~mL}$ of cell suspension from the freeze-dried cells at $10^{9} \mathrm{cfu}^{-1}$ was washed successively in $1 \mathrm{~mL}$ of phosphate buffer solution (PBS) and centrifuged at 12500 rpm. Then, it was stained with $10 \mu \mathrm{L}$ of cFDA or PI and incubated at $37^{\circ} \mathrm{C}[20,21]$. Tubes were washed three times with PBS and analyzed on FACSCalibur two lasers flow cytometer. cFDA and PI were excited by a $488 \mathrm{~nm}$ laser; the signal was red from the cFDA in the FL-1 and that of PI in the FL-3. All experiments were repeated three times.

\subsubsection{Soluble Proteins}

The amounts of the cell soluble protein concentration were analyzed using Lowry et al.'s [22] method from $0.5 \mathrm{~g}$ freeze-dried cells after sonication (Bandelin Sonopuls HD 2070, Germany) with Fohlin-Ciocalteu reagent.

\subsubsection{Carbonyl Proteins}

The determination of carbonyl compounds was obtained spectrophotometrically by derivatization of the carbonyl group with 2,4-dinitrophenylhydrazine (DNPH) using Levine's (2002) modified method of labeling, leading to the formation of a stable 2,4-dinitrophenyl (DNP) hydrazone product. Dried cells were lysed by sonication (Bandelin Sonopuls HD 2070, Germany) and were centrifuged (1500 $\mathrm{rpm}, 10 \mathrm{~min}$ at $4^{\circ} \mathrm{C}$ ). Thereafter, $0.2 \mathrm{ml}$ was collected and incubated with $0.8 \mathrm{ml} 0.2 \% \mathrm{DNPH}$ in $2.5 \mathrm{M} \mathrm{HCl}$ for $1 \mathrm{~h}$ at room temperature. Then, the derivative protein contents were extracted with $10 \%(\mathrm{w} / \mathrm{v})$ trichloroacetic acid, treated with ethanol/ethyl acetate $1: 1(\mathrm{v} / \mathrm{v})$ and re-extracted with $10 \%$ trichloroacetic acid. The precipitated extract was dissolved in $6 \mathrm{M}$ guanidine hydrochloride. A blank without the DNPH reagent but with $2 \mathrm{M} \mathrm{HCl}$ was treated in parallel following the same procedure. The protein carbonyl content of dried cells was calculated using a standard curve prepared from BSA standards. Carbonyl/protein contents were determined by absorption at $360 \mathrm{~nm}$ and expressed in $\mathrm{nmol} / \mathrm{mg}$ [23, 24].

\subsubsection{Statistical Analysis}

Productions were done in three bioreactors. The mean values and the standard deviation were obtained from the triplicate.

\section{Results and Discussion}

The strain CWBI-B1465 was produced in a $20 \mathrm{~L}$ bioreactor in batch and fed-batch processes primarily for the 
estimation of the yield of production. The working volume was $16 \mathrm{~L}$. One half was then dried by freeze-drying and the other half was spray-dried. The results express a comparative study of growth parameters and conversion yield on the basis of two fermentation modes (batch and fed-batch) followed by two drying processes (freeze-drying and spray-drying). Second, the viability of the strain CWBI-B1465 in storage was examined and compared only on dried cells produced by batch mode. Here, a multiparameter analysis was applied for the viability assessment.

\subsection{Production in 20 L Fermentor of CWBI-B1465 Leuconostoc Mesenteroides JF313445}

The growth was performed at $27^{\circ} \mathrm{C}$ and at a $\mathrm{pH}$ of 6.5 in MRS broth. The agitation was adjusted at $100 \mathrm{rpm}$. For the batch process, the growth data were estimated with the end of the exponential phase at seven hours. For the fed-batch process, the second glucose was added after six hours and the exponential phase ended at nine hours. A half liter pre-culture allowed for direct growth in the fermentor without a significant lag phase. The cell concentrations, as illustrated in Table 1 at the end of fermentation, were 9.78 $\log$ cfu.ml ${ }^{-1}$ in batch, and $11.8 \log$ cfu. $\mathrm{ml}^{-1}$ in the fed-batch, the figure was. This involves an increase of $20.66 \%$ only due to the action of $320 \mathrm{~g}$ additional glucose dissolved in $1 \mathrm{~L}$ of distilled water and added in the fermentor for the fed-batch process. Correspondingly, the growth was 74 times in the first phase of the fed-batch (at 6h) and 142 times at the end from the second inoculation. The specific growth rates $(\mu)$ were 0.61 and $0.55 \mathrm{~h}^{-1}$ in the batch and fed-batch, respectively, and the generation times $(\operatorname{tg})$ were 1.12 and $1.25 \mathrm{~h}$ in the batch and fed-batch, respectively.

Table 1. Production in 20 L fermentor of CWBI-B1465 Leuconostoc mesenteroides subsp. mesenteroides JF313445.

\begin{tabular}{|c|c|c|c|c|c|c|}
\hline Processes & Fermentation time(h) & End of fermentation cells concentration $\left(\log\right.$ cfu.mL $\left.L^{-1}\right)$ & ${ }^{1} \boldsymbol{\mu}\left(\mathbf{h}^{-1}\right)$ & ${ }^{2} \operatorname{tg}(h)$ & ${ }^{3} Y_{x / s}\left(g \cdot g^{-1}\right)$ & \\
\hline \multirow{3}{*}{ Batch } & \multirow{3}{*}{7.33} & \multirow{3}{*}{$9.78 \pm 0.17$} & \multirow{3}{*}{$0.61 \pm 0.01$} & \multirow{3}{*}{$1.12 \pm 0.02$} & $0.15 \pm 0.00$ & ${ }^{4} \mathrm{FD}$ \\
\hline & & & & & & \\
\hline & & & & & $0.15 \pm 0.02$ & ${ }^{5} \mathrm{SD}$ \\
\hline Fed-batch & 9.50 & $11.08 \pm 0.05$ & $0.55 \pm 0.07$ & $1.25 \pm 0.02$ & $0.16 \pm 0.02$ & FD \\
\hline
\end{tabular}

${ }^{1} \mu$ : the specific growth rate; ${ }^{2} \operatorname{tg}$ : the generation time; ${ }^{3} \mathrm{Y}_{\mathrm{x} / \mathrm{s}}$ : conversion yield coefficient; ${ }^{4} \mathrm{FD}$ : freeze-drying; ${ }^{5} \mathrm{SD}$ : spray- drying.

Ziadi et al. [25] found about $0.9 \mathrm{~h}^{-1}$ of $\mu$ max and 0.7 of tg for two lactococci strains produced in fed-batch in M17 medium. These data are in agreement with the growth behavior of the two genera, as it's well known that generally Lactococcus grow more quickly than Leuconostoc.

\subsection{Viability of CWBI-B1465 Leuconostoc Mesenteroides JF313445 to Freeze-Drying Vs Spray-Drying}

Cells grown in a $20 \mathrm{~L}$ bioreactor (in batch and fed-batch) were harvested, concentrated by centrifugation and thereafter protected by addition of protective agents.
A half was freeze-dried, whilst another half was spray-dried. Data of viable cells are presented in table 2 . The batch process followed by freeze-drying showed a viable count of $11.90 \pm 1.04 \log$ cfu. $\mathrm{g}^{-1}$, while viable population resulted from the batch followed by spray-drying was $10.74 \pm 0.11 \log$ cfu.g-1. The two values represented respectively the survival rates $(\%)$ of 27.8 and 21.2 which showed clearly how the freeze-drying mode [26, 27] proved effective in achieving high viable cells. However, the value obtained by spray-drying is very interesting in terms of the cost of the processes.

Table 2. Effect of drying process on the viability of CWBI-B1465 Leuconostoc mesenteroides JF313445.

\begin{tabular}{|c|c|c|c|c|c|c|}
\hline \multirow{2}{*}{ Process } & \multicolumn{2}{|l|}{ Before drying } & \multicolumn{2}{|l|}{ After drying } & \multirow{2}{*}{\multicolumn{2}{|c|}{ Survival rate $(\%)$}} \\
\hline & ${ }^{1}$ Concentration (log cfu.mL $\left.L^{-1}\right)$ & Dry matter (\%) & ${ }^{2}$ Concentration (log cfu.g $\left.{ }^{-1}\right)$ & Dry matter (\%) & & \\
\hline \multirow{3}{*}{ Batch } & $11.90 \pm 1.04$ & $24.58 \pm 0.52$ & $11.43 \pm 0.31$ & $91.88 \pm 1.29$ & 27.85 & ${ }^{3} \mathrm{FD}$ \\
\hline & & & & & & \\
\hline & $10.74 \pm 0.11$ & $19.71 \pm 0.46$ & $10.68 \pm 0.10$ & $93.35 \pm 1.00$ & 21.23 & ${ }^{4} \mathrm{SD}$ \\
\hline Fed-batch & $11.44 \pm 0.25$ & $22.42 \pm 0.86$ & $11.08 \pm 0.05$ & $91.65 \pm 0.45$ & 23.89 & FD \\
\hline
\end{tabular}

${ }^{1}$ biomass before drying; ${ }^{2}$ biomass after drying; ${ }^{3} \mathrm{FD}$ : freeze-drying; ${ }^{4} \mathrm{SD}$ : spray-drying

And comparing the batch and the fed-batch processes followed by the freeze-drying, it was also proven that the batch process seems to be the best as the fed-batch had only $23.89 \%$ of viable free-dried cells. In all cases, the cells recovery after the drying process (FD or SD) was more than $96 \%$ and the dry matters were $>91 \%$. Even if there was a decrease in viability after the drying process [28], the survival rates after drying processes were somehow high. 
Coulibaly et al. [19] found $18 \%$ in the same conditions on another freeze-dried strain of Leuconostoc mesenteroides, meaning that our Leuconostoc was very resistant.

\subsection{Viability of Freeze/Spray-Dried Cells in Storage}

During storage on 90 days, the enumeration showed a decrease in time with freeze- spray-dried cells produced by batch process. Powders stored at $4{ }^{\circ} \mathrm{C}$ were reduced of $1.8 \%$ for freeze-dried cells and $2.3 \%$ for spray-dried cells. At $20^{\circ} \mathrm{C}$, the decrease was very high with $46.0 \%$ and $42.1 \%$ respectively. These data showed again that freeze-drying is the best preservation technique, but the difference is very low. Viability assessment was also evaluated through the fatty acids extracted from cell membrane and the physiological state of cells by flow cytometry analyses. Analyses of the oxidation of cellular constituents were also carried out for cells viability estimation. For that issue, carbonyl proteins and soluble proteins contents were analyzed after sonication of dried powders stored for 90 days.

\subsubsection{Fatty Acids Extracted from Cell Membrane}

The cellular fatty acids (CFAs) composition in this study has been examined for linking cells viability to conditions of storage during 90 days at two temperatures: $4^{\circ} \mathrm{C}$ and $20^{\circ} \mathrm{C}$. Freeze-dried cells (FD) and spray-dried (SD) cells were compared with regard to the fatty acids oxidation. As well known, the lipid oxidation of membrane fatty acids is deemed responsible for cell death during storage [29-32]. Each CFA relative percentage has been calculated from the total fatty acid methyl esters. The data are means of three independent experiments and the coefficients of variability were lower than $5 \%(\mathrm{p}<0.05)$.

Seven major fatty acids (CFAs) were found as illustrated on Figs. $1 \& 2$. They are meristic acid (C14); palmitic acid (C16); palmitoleic acid (C16:1); stearic acid (C18); oleic acid (C18:1); linoleic acid (C18:2t); linolenic acid (C18:3t). Among the 7 CFAs, palmitic acid and palmitoleic acid represented more than $70 \%$. We have calculated the decrease of unsaturated fatty acids due to oxidation based on the ratio between each polyunsaturated fatty acid and the palmitic acid, since saturated fatty acids are not altered by oxidation. The ratio $\mathrm{C} 14: 0 / \mathrm{C} 16: 0 ; \mathrm{C} 18: 0 / \mathrm{C} 16: 0 ; \mathrm{C} 18: 2 \mathrm{t} / \mathrm{C} 16: 0$ stays unchanged for 90 days at $4^{\circ} \mathrm{C}$ and $20^{\circ} \mathrm{C}$ for freeze/spray-dried powders. The changes occurred on freeze-dried cells as following: at $4{ }^{\circ} \mathrm{C}$, the ratio $\mathrm{C} 18: 1 / \mathrm{C} 16: 0$ decreases for $2.2 \%$, whilst it decreases by $4.8 \%$ at $20^{\circ} \mathrm{C}$. At the two temperatures, the changes are very low so that the oxidation phenomenon does not affect the viability.

On spray-dried cells, decreases were observed on the ratio $\mathrm{C} 16: 1 / \mathrm{C} 16: 0$. At $4{ }^{\circ} \mathrm{C}$, the ratio $\mathrm{C} 18: 1 / \mathrm{C} 16: 0$ decreased by $3.0 \%$ and by 4.1 at $20^{\circ} \mathrm{C}$. Slight decrease was also present on the ratio $\mathrm{C} 18: 3 \mathrm{t} / \mathrm{C} 16: 0$ for $6.9 \%$ at $20^{\circ} \mathrm{C}$. Globally, it seems that the phenomenon of oxidation is very low and its value may be beared on the palmitoleic acid, the oleic acid and the linolenic acid in storage.

Our results disagreed with data obtained by Coulibaly et al. [19] on another strain of Leuconostoc mesenteroides. He found decreases on the ratio $\mathrm{C} 18: 2 / \mathrm{C} 16: 0$ and $\mathrm{C} 18: 3 / \mathrm{C} 16: 0$. In general, CWBI-B1465 Leuconostoc mesenteroides stayed stable at $4{ }^{\circ} \mathrm{C}$ for freeze-dried cells and spray-dried cells. But our results were consistent with our hypothesis that the strain CWBI-B1465 Leuconostoc mesenteroides is highly resistant.

\subsubsection{Flow Cytometry Analyses}

The flow cytometry analyses were applied for the assessment of the impact of the drying process on cells viability in storage. Prior to flow cytometry analyses on dried cells, cFDA (carboxyfluorescein diacetate) and PI (propidium iodide) were tested for control on CWBI-B1465 Leuconostoc mesenteroides fresh cells supposed to be at 100 $\%$ alive and on $100 \%$ fully heat-killed cells, as well as a multiparameter dot plot obtained after PI/cFDA double staining of their mixture (at a ratio of $1: 1 \mathrm{vol} / \mathrm{vol}$ ). These cells were not submitted to any drying process and were collected in exponential phase for $100 \%$ living cells and a fraction was heat-killed for dead cells. Living cells and dead cells subpopulations were spatially separated in dot plots of FL1 and FL2; and relative percentages obtained on living cells stained with cFDA showed $99.11 \%$ of viable cells, $0.01 \%$ of dead cells and $0.74 \%$ of intermediate cells (viable but non cultivable); whereas living cells stained by PI gave $0.08 \%$ alive cells, $9.49 \%$ of dead cells, $0.11 \%$ of intermediate cells and $90.32 \%$ of non stained cells (LL). Data obtained (Fig. 3) with fully dead cells were $0.0 \%$ of dead cells, $0.0 \%$ of intermediate cells; $99.99 \%$ of non-stained cells (LL) and $0.01 \%$ living cells for cells stained with cFDA; whilst $99.98 \%$ of dead cells, $0.0 \%$ of intermediate cells and $0.0 \%$ alive cells for cells stained with PI.

These findings enabled us the use of the double staining cFDA/PI for a live/dead discrimination, as live/dead assays with two differentially staining probes are attractive because detection is easier when all cells are labeled [20]. 


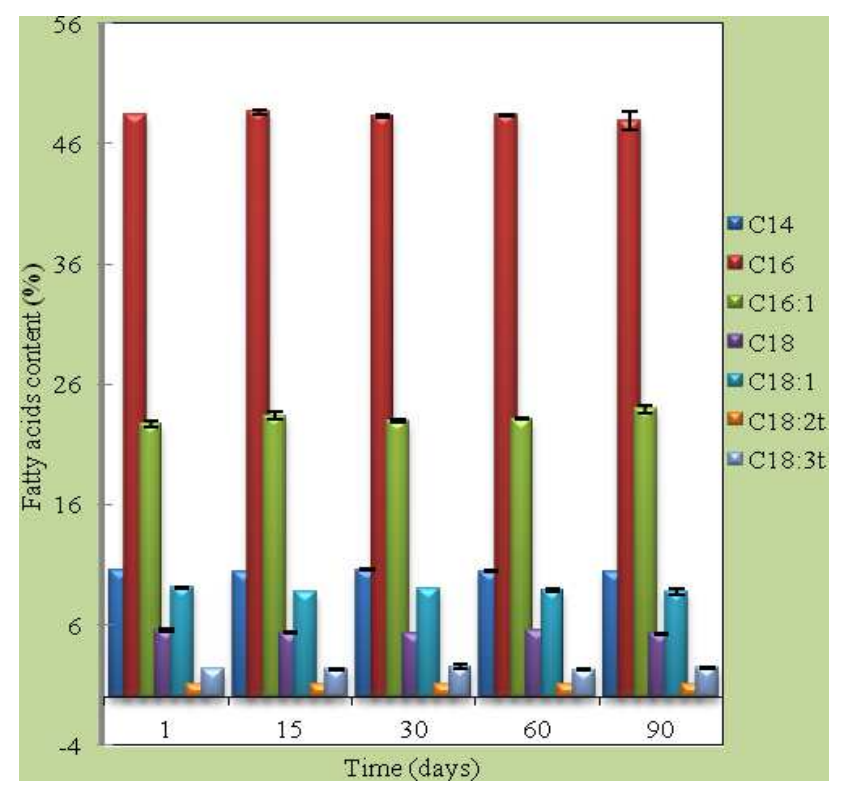

(FD)

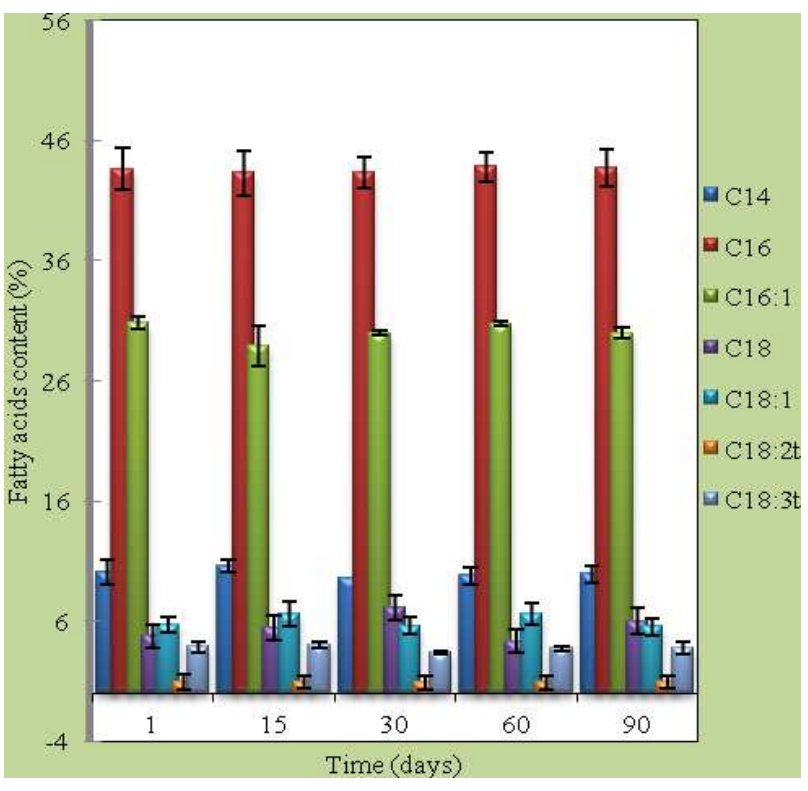

(SD)

Figure 1. Cellular fatty acids contents of freeze-dried (FD) vs spray-dried (SD) CWBI-B1465 Leuconostoc mesenteroides during 90 days at $4^{\circ} \mathrm{C}$. Meristic acid (C14); palmitic acid (C16); palmitoleic acid (C16:1); stearic acid (C18); oleic acid (C18:1); linoleic acid (C18:2t); linolenic acid (C18:3t); SFA (Saturated Fatty Acids): C14:0; C16:0; C18:0; UFA (unsaturated fatty acids): C16:1; C18:1; C18:2t; C18:3t. Values are means of 3 experiments. Content in \%.

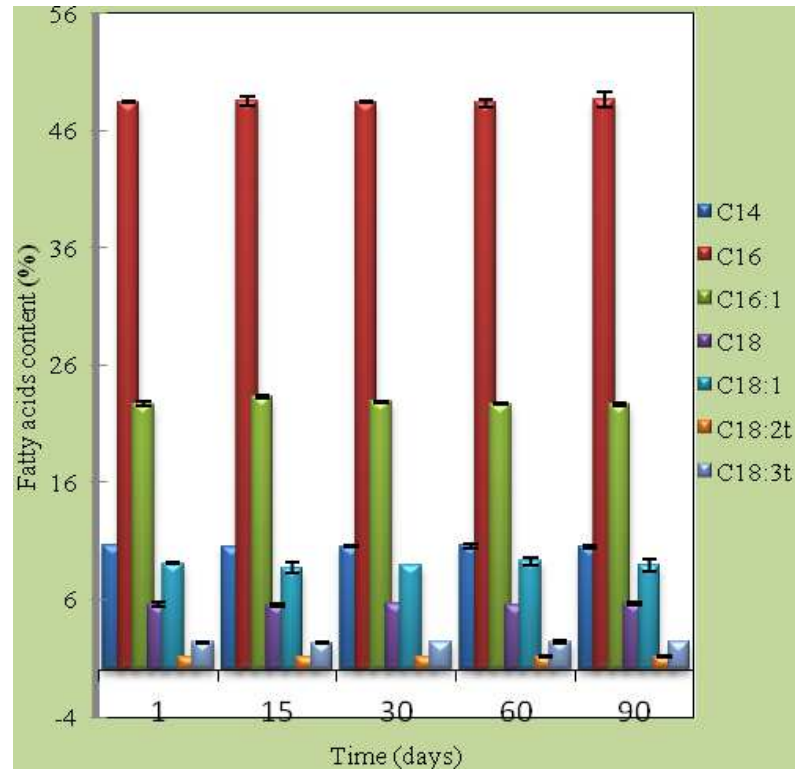

(FD)

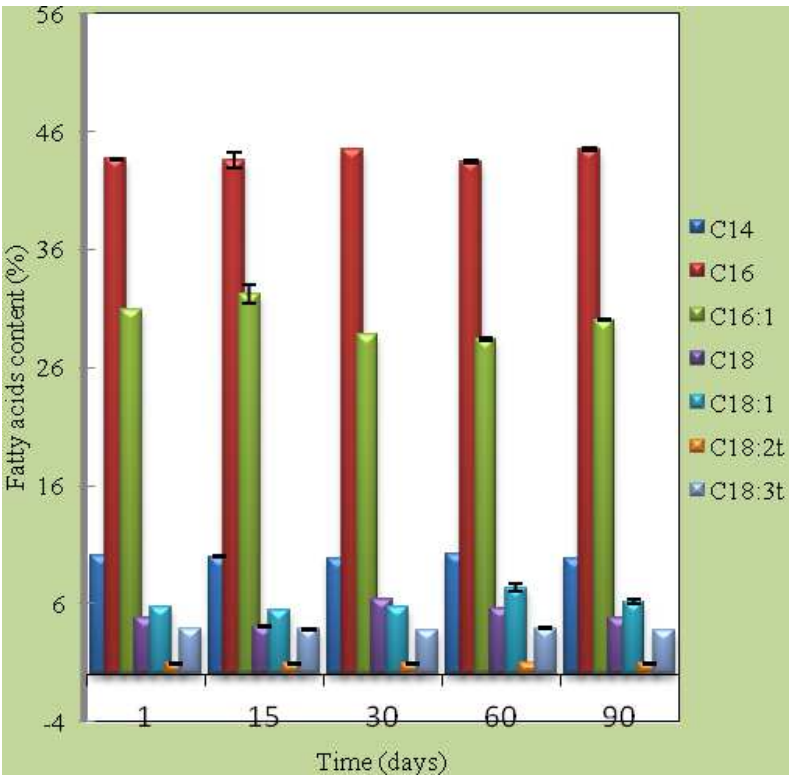

(SD)

Figure 2. Cellular fatty acids contents of freeze-dried (FD) vs spray-dried (SD) CWBI-B1465 Leuconostoc mesenteroides during 90 days at $20^{\circ} \mathrm{C}$. Meristic acid (C14); palmitic acid (C16); palmitoleic acid (C16:1); stearic acid (C18); oleic acid (C18:1); linoleic acid (C18:2t); linolenic acid (C18:3t); SFA (saturated fatty acids): C14:0; C16: 0; C18:0; UFA (unsaturated fatty acids): C16:1; C18:1; C18:2t; C18:3t. Values are means of 3 experiments. Content in \%. 


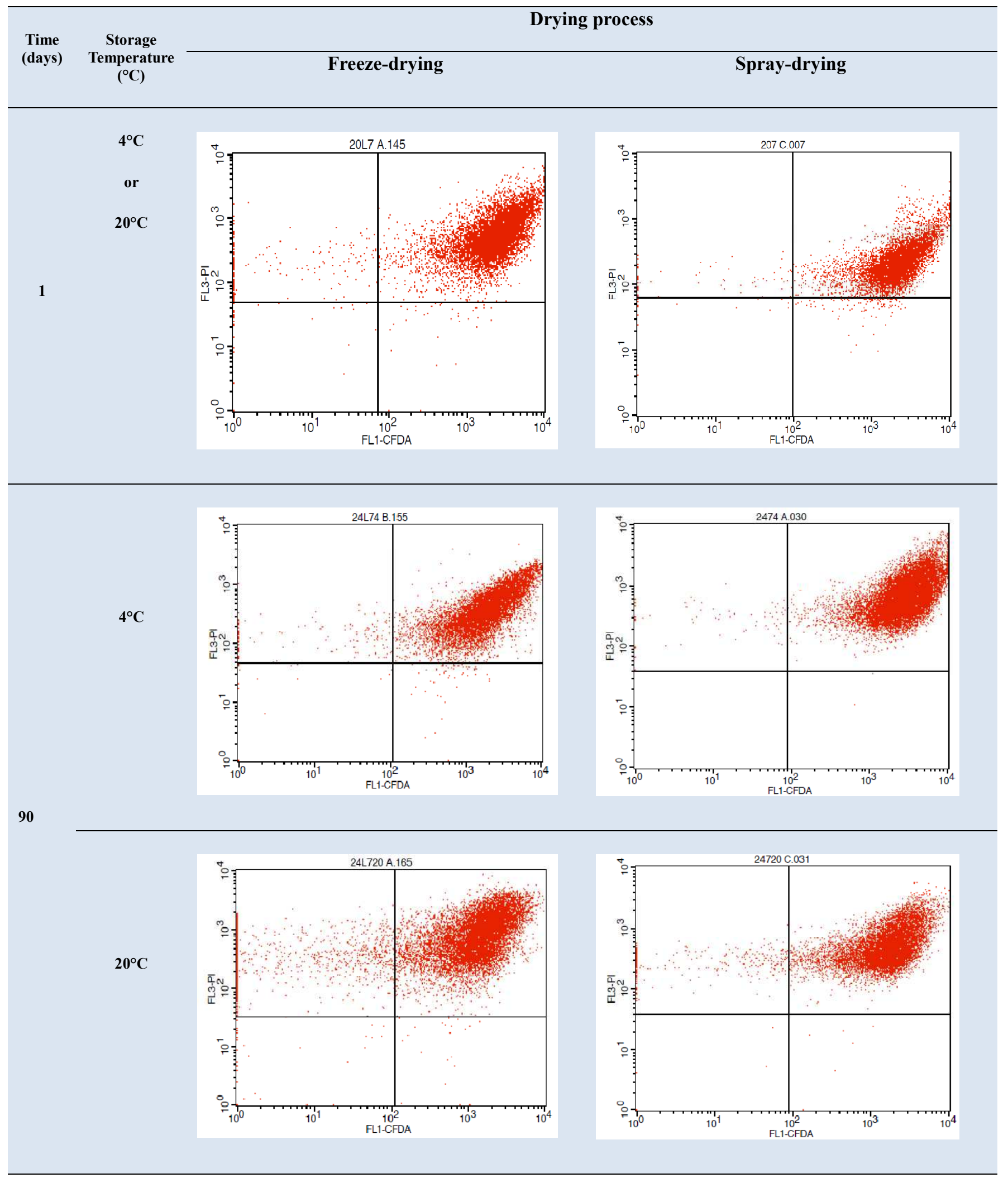

Figure 3. Flow cytograms of CWBI-B1465 Leuconostoc mesenteroides in storage. Cells were freeze-dried and spray-dried, stored at two temperatures 4 and $20^{\circ} \mathrm{C}$ during 90 days. Flow cytograms shown here were analyzed at the initial time (day 1) and the end of storage time (day 90)3.3.3. Soluble proteins (SP).

Analyses of protein contents in freeze/spray-dried powders stored at $4{ }^{\circ} \mathrm{C}$ and $20^{\circ} \mathrm{Cwas}$ also carried out on 90 days. Measurements were made at day 1 (after the drying process), day 15 , day 30 , day 60 and day 90 . Results of dried cells (fig. 4) stored at $4{ }^{\circ} \mathrm{C}$ showed that there is a slight decrease for freeze-dried cells $88 \%$ to $87 \%$ and from $88 \%$ to $85 \%$ for spray-dried cells which is not significant in terms of the process yield. 
However, for cells stored at $20^{\circ} \mathrm{C}$ (figure 5), the decrease of freeze-dried cells was in the range of $88 \%$ to $80 \%$, whereas the range was very high from $88 \%$ to $64.19 \%$ for spray-dried cells. In all cases, the decrease is an indication of protein oxidation, which is expressed by protein insolubilization. And the slope of this phenomenon showed that the insolubilization is higher in freeze-dried cells than in spray-dried cells

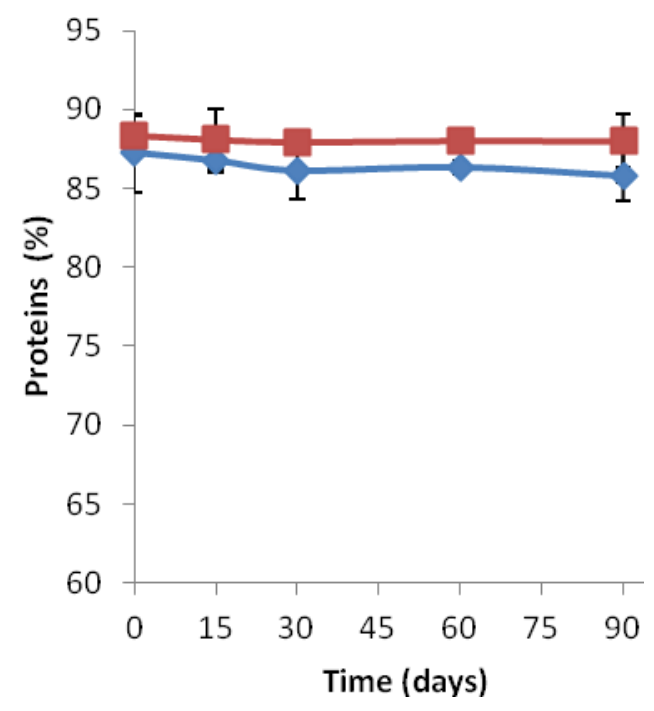

Figure 4. Soluble proteins content (\%) during 90 days storage at $4^{\circ} \mathrm{C}$ of CWBI-B1465 Leuconostoc mesenteroides ( $\mathbf{f r e e z e - d r i e d ~ a n d}$ spray-dried).

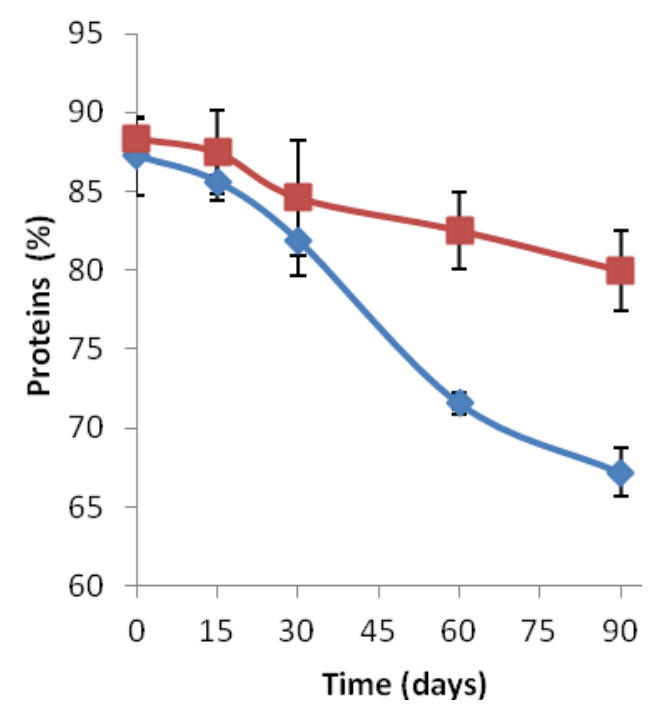

Figure 5. Soluble proteins content (\%) during 90 days storage at $20^{\circ} \mathrm{C}$ of CWBI-B1465 Leuconostoc mesenteroides ( $\square$ freeze-dried and spray-dried).

\subsubsection{Carbonyl Proteins Contents (CP)}

The carbonyl contents in freeze/spray-dried cells were compared as for soluble proteins. Freeze-dried cells have more carbonyl contents than spray-dried cells (figs. $6 \& 7$ ), about 3 folds. And we observed a slow growth during the storage at $4^{\circ} \mathrm{C}$ in the two cases. The growth was very high at $20^{\circ} \mathrm{C}$ storage also in both cases. An increase of carbonyl contents is an indication of the oxidation phenomenon.

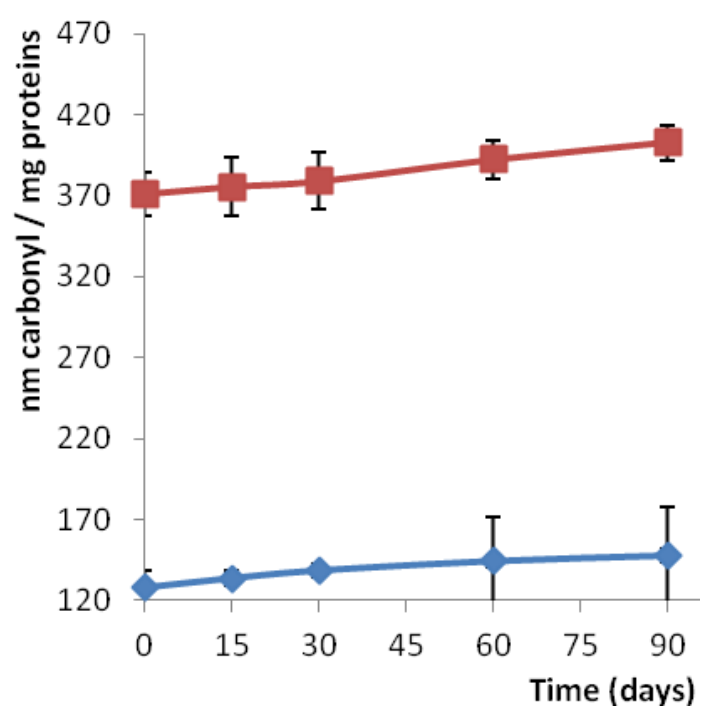

Figure 6. Protein carbonyl content (nmol/mg) during 90 days storage at $4^{\circ} \mathrm{C}$ of CWBI-B1465 Leuconostoc mesenteroides ( $\$$ freeze-dried and spray-dried).

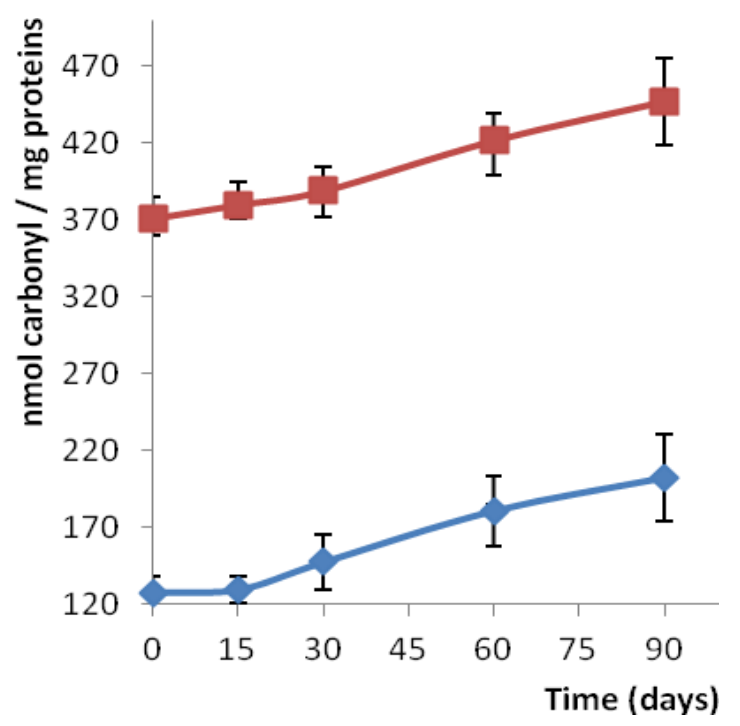

Figure 7. Protein carbonyl content (nmol/mg) during 90 days storage at $20^{\circ} \mathrm{C}$ of CWBI-B1465 Leuconostoc mesenteroides ( freeze-dried and spray-dried).

\section{Conclusion}

The dried bacteria are subject to relative high viability loss from the concentration, and through the drying process as well as during storage. The strain CWBI-B1465 Leuconostoc mesenteroides can be produced in bioreactor in biomass concentration of $10^{10} \mathrm{cfu} . \mathrm{g}^{-1}$ by batch mode. In order to increase this biomass, the application of fed-batch mode is required. The generation time is therefore near $1.2 \mathrm{~h}$, which stays low than Lactococcus or Lactobacillus strains. It is 
however in the range of growth characteristic of Leuconostoc strains. Cells produced can be either freeze-dried or spray-dried, as this strain showed good yields in both cases.

\section{Acknowledgements}

The authors are gratefull to Gembloux Agro Bio-Tech ULG, the CUD (Communauté Universitaire pour le Développement, Belgique) and the CWBI for the financial support, the Cytometry Group Giga ULG for the analytical assistance. We also acknowledge specially Thiry C., Fontaine F., Telek S. and Massaut B. for technical assistance.

\section{References}

[1] Gardiner G, O’Sullivan E, Kelly J, Auty MAE, Fitzgerald GF, Collins JK, Ross RP, Stanton C. 2000. Comparative survival of human-derived probiotic Lactobacillus paracasei and L. salivarius strains during heat treatment and spray-drying. Appl Environ Microbiol. 66: 2605-2612.

[2] Collins JK, Thornton G, Sullivan GO. 1998. Selection of Probiotic Strains for Human Applications. Int D J. $8(5-6): 487-490$

[3] Holzapfel WH, Schillinger U. 2002. Introduction to pre- and probiotics. Food Res Int. 35:109-116.

[4] Stanton C, Desmond C, Coakley M, Collins JK, Fitzgerald G, Ross RP. 2003. Challenges facing development of probiotic-containing functional foods. In Handbook of Fermented Functional Foods. Edited by Farnworth ER. Boca Raton: CRC Press; 27-58.

[5] Golowczyc MA, Silva J, Abraham AG, De Antoni GL, Teixeira P. 2010. Preservation of probiotic strains isolated from kefir by spray-drying. Lett Appl Microbiol. 50: 7-12

[6] Grune T, Catalgol B, Jung T. 2013. Protein oxidation and aging: different model systems and affecting factors. In Protein oxidation and aging. Edited by Uverski VN. Hoboken: Wiley Inc; 295-370.

[7] Coulibaly I, Dubois-Dauphin R, Danthine S, Majad L, Mejoub T, Destain J, Béra F, Wathelet J-P, Thonart P. 2011. Techniques de séchage des starters lactiques et mécanismes affectant la viabilité cellulaire suite à la lyophilisation. Biotechnol Agro Soc. 15(2): 287-299

[8] Møller IM, Rogowska-Wrzesinska A, Rao RS. 2011. Protein carbonylation and metal-catalyzed protein oxidation in a cellular perspective. J Proteomics. 74(11): 2228-2242.

[9] Dalle-Donne I, Giustarini D, Colombo R, Rossi R, Milzani A. 2003. Protein carbonylation in human diseases. Trends Mol Med. 9(4): 169-176.

[10] Yoon SJ, Park JE, Yang JH. Park JW. 2002. OxyR Regulon Controls Lipid Peroxidation-mediated Oxidative Stress in Escherichia coli. J Biochem Mol Biol. 35: 297-301.

[11] Fleming JE, Miguel J, Cottrell SF, Yengoyan LS, Economos AC. 1982. Is cell aging caused by respiration dependent injury to the mitochondrial genome? Gerontology. 28: 44-53.

[12] Kalemba EM, Pukacka S. 2014. Carbonylated proteins accumulated as vitality decreases during long-term storage of beech (Fagus sylvatica L.) seeds. Trees. 28:503-515.

[13] Levine RL, Williams JA, Stadtman EP, Shacter E. 1994. Carbonyl assays for determination of oxidatively modified proteins. Method Enzymol. 233: 346-357.

[14] Levine LR. 2002. Carbonyl modified proteins in cellular regulation, aging and disease. Free Radic Biol Med. 32:790-796.

[15] Karenzi E, Dauphin RD, Mashaku A, Majad L, Munyanganizi B, Thonart P. 2012. Fermentation of kivuguto, a Rwandese traditional milk: selection of microbes for a starter culture. Sci. Technol.36: 9-17.

[16] De Vuyst L, Callewaert R, Crabbe K. 1996. Primary metabolite kinetics of bacteriocin biosynthesis by Lactobacillus amylovorus and evidence for stimulation of bacteriocin under unfavourable growth conditions. Microbiology. 142: 817-827.

[17] IDF. 1993. Inhibitory substance in milk- Current analytical practice. Bulletin of the IDF 283. IDF. Brussels, Belgium.

[18] Zelles L. 1999. Fatty acid patterns of phospholipids and lipopolysaccharides in the characterization of microbial communities in soil: a review. Biol Fert Soils. 29: 111-129.

[19] Coulibaly I, Amenan AY, Lognay G, Fauconnier ML, Thonart P 2009. Survival of freeze-dried Leuconostoc mesenteroides and Lactobacillus plantarum related to their cellular fatty acids composition during storage. Appl Biochem Biotechnol. 157:70-84

[20] Bunthof CJ, Bloemen K, Breeuwer P. 2001. Lactic acid bacteria flow cytometric assessment of viability of lactic acid bacteria. Appl Environ Microbiol. 67(5): 2326-2335.

[21] Rault A, Béal C, Ghorbal S, Ogier J-C, Bouix M. 2007. Multiparametric flow cytometry allows rapid assessment and comparison of lactic acid bacteria viability after freezing and during frozen storage. Cryobiology. 55:35-43.

[22] Lowry O.H., Rosebrough N.J., Farr A.L. and Randall R.J., 1951. Protein measurement with the Folin phenol reagent. J Biol Chem. 193:265-275.

[23] Kim SY, Kim EJ, Park JW. 2002. Control of singlet Oxygen-induced oxydative damage in Eschericia coli. Biochem Mol Biol. 35:353-357.

[24] Luqman S, Rizvi SI. 2006. Protection of lipid peroxidation and carbonyl formation in proteins by capsaicin in human erythocytes subjected to oxidative stress. Phytother Res. 20:303-306.

[25] Ziadi M, M'hir S, Mrabet A, Thonart P, Hamdi M. 2008. Production and freeze-drying of Leben lactic starter. Res J Microbiol. 4(1):35-48.

[26] Yao AA, Dortu C, Egounlety M, Pinto C. et al. 2009. Production of freeze-dried lactic acid bacteria starter culture for cassava fermentation into gari. Afr $\mathrm{J}$ Biotechnol. 8(19):4996-5004.

[27] Miyamoto-Shinohara Y, Imaizumi T, Sukenobe J, Murakami Y, Kawamura S, Komatsu Y. 2000. Survival rate of microbes after freeze-drying and long term storage. Cryobiology. 4:251-255.

[28] Castro HP, Teixeira PM, Kirby R. 1997. Evidence of membranes damage in Lactobacillus bulgaricus following freeze-drying. J Appl Microbiol. 82:87-94. 
[29] Mputu-Kanyinda JN, Pierart C, Weekers F, Destain J, Thonart P. 2012. Impact of protective compounds on the viability, physiological state and lipid degradation of freeze-dried Pseudomonas fluorescens BTP1 during Storage. Int J Biotechnol Biochem. 8(1):17-26.

[30] Andersen AB, Fog-Petersen MS, Larsen H, Skibsted LH. 1999. Storage stability of freeze-dried starter cultures (Streptococcus thermophilus) as related to physical state of freezing matrix.
Lebensm Wiss Technol. 32:540-547.

[31] Teixeira P, Castro H, Kirby R. 1996. Evidence of membrane lipid oxidation of spray-dried Lactobacillus bulgaricus during storage. Lett Appl Microbiol. 22(1):34-38.

[32] Teixeira PC, Castro MH, Malcata FX, Kirby RM. 1995. Survival of Lactobacillus delbrueckii ssp. bulgaricus following spray-drying. J D Sci. 78:1025-1031. 